\title{
Rare Carboniferous and Permian glacial and non-glacial bryophytes and associated lycophyte megaspores of the Paraná Basin, Brazil: A new occurrence and paleoenvironmental considerations
}

\author{
Fresia Ricardi-Branco ${ }^{\text {a, * }}$, Rosemarie Rohn ${ }^{\text {b }}$, Marcia Emilia Longhim c, \\ Juliana Sampaio Costa ${ }^{\mathrm{d}}$, Ariel Milani Martine ${ }^{\mathrm{d}}$, Isabel Cortez Christiano-de-Souza ${ }^{\mathrm{d}}$ \\ a Instituto de Geociências, Universidade Estadual de Campinas, Campinas, SP, Postal Zone 13083-970, P. Box 6152, Brazil \\ ${ }^{\mathrm{b}}$ Instituto de Geociências e Ciências Exatas, Departamento de Geologia Aplicada, Universidade Estadual Paulista, Campus de Rio Claro, Rio Claro, SP, Postal \\ Zone 13506-900, P. Box 178, Brazil \\ ' Gerencia de Bioestratigrafia e Paleoecologia Aplicada, PDGEO, CENPES, PETROBRAS, Rio de Janeiro, RJ, Av. Horacio Macedo, 950 - prédio, 20 sala, 1112 Ilha \\ do Fundão, Postal Zone 21941-915, Brazil \\ ${ }^{\mathrm{d}}$ Programa de Pós-graduação em Geociências, Instituto de Geociências, Universidade Estadual de Campinas, Campinas, SP, Postal Zone 13083-970, P. Box \\ 6152, Brazil
}

\section{A R T I C L E I N F O}

\section{Article history:}

Received 9 May 2016

Received in revised form

19 July 2016

Accepted 20 July 2016

Available online 22 July 2016

\section{Keywords:}

Mosses

Pleurocarps

Megaspores

Late Paleozoic

Paleoclimatology

Glaciation

Tundra

\begin{abstract}
A B S T R A C T
Fossil bryophytes are rare because their preservation is compromised by the presence of a thin cuticle (if any) and a lack of lignin. Except for the occurrence of one bryophyte in the glacial Dwyka Group of the Karoo Basin, the other rare Late Paleozoic records in Gondwana are notably from the Paraná Basin in Southeast/South Brazil. Four bryophyte sites (including a newly discovered one) were found in the lower part of the thick Permo-Carboniferous glacial succession of the Itararé Group, and one was found in the Guadalupian Teresina Formation, which was roughly assigned to an epeiric sea (or "lake") dominated by a warm, semi-arid climate. This study describes the fossils from the new occurrence from the Itararé Group and discusses the context in which the bryophyte beds originated in the basin. The new samples confirm that all of the bryophytes of the Itararé Group can be classified as Dwykea araroii Ricardi-Branco et al. (a possible pleurocarp) and are associated with the lycophyte megaspore Sublagenicula brasiliensis (Dijkstra) Dybová-Jachowicz. In the much younger Teresina Formation, the bryophytes are Yguajemanus yucapirus Cristiano-de-Souza et al. and Capimirinus riopretensis Cristiano-de-Souza et al., and abundant charophytes and rare dwarf lycophyte stems and bracts are present in the same layers. Although the two stratigraphic units represent distinct paleoenvironments and climates, they seem to share some characteristics: a) the bryophyte assemblages were transported very little; b) they were deposited in very calm environments; c) they were the main components (along with some lycophytes) of local or poorly diversified regional vegetation. The low number of species, which is characteristic of opportunistic communities, can be explained by local or regional conditions that would have been stressful for the vascular plants in other areas. During the deposition of the Itararé Group, the main control was probably the cold climate in addition to a relative (liquid) water deficit because the bryophyte vegetation may have belonged to a tundra biome in areas of retreating glaciers. For the Teresina Formation, it is possible that the control was scarce freshwater, an unstable environment and water-saturated soil in a scenario of bryophyte vegetation living around temporary ponds in a wide marginal area of the epeiric sea.
\end{abstract}

(C) 2016 Elsevier Ltd. All rights reserved.

\footnotetext{
* Corresponding author.

E-mail addresses: fresia@ige.unicamp.br (F. Ricardi-Branco), rohn@rc.unesp.br (R. Rohn), melonghim@petrobras.com.br (M.E. Longhim), sampaiojcosta@gmail. com (J.S. Costa), ariel_bia@yahoo.com.br (A.M. Martine), isabel.cortez@ige. unicamp.br (I.C. Christiano-de-Souza).
}

\section{Introduction}

Mosses (Class Bryophyta), in contrast to tracheophytes, are small, fragile "non-vascular" plants, which are generally without conducting tissues and lack lignin (Taylor et al., 2009). A particularly distinctive characteristic of bryophytes is the dominance of the 
haploid (gametophyte) generation in their life cycle, including the possibility of an occasional sporophyte phase (Frey, 2009; Taylor et al., 2009). Acrocarpic specimens found in the Mississippian of Germany, which are related to ancestral forms, are traditionally believed to be the oldest fossil mosses (http://www.amjbot.org/ content/102/11/1883.fullHübers and Kerp, 2012), and the earliest pleurocarpic mosses are evidenced in the Permian of Gondwana (Cristiano-de-Souza et al., 2012; Johnson et al., 2016). However, the Mesozoic moss record is more diverse than that of the Late Paleozoic (Shelton et al., 2015).

Some Devonian fossils are similar to bryophytes, but their affinities are uncertain, or they probably belong to other plant groups. One example is the Upper Devonian fossil that was first designated as Hepaticites devonicus Hueber (1961) and later moved to Pallavicinites (Goffinet et al., 2009). According to biophysical and morphological criteria as the size, Boyce (2008) suggested that Silurian-Early Devonian cooksonioid specimens may correspond to moss sporophytes, which may have been too small for sufficient aerated photosynthetic tissue. Gerrienne et al. (2006) proposed that the supposedly Eutracheophyta Cooksonia paranaensis from the Paraná Basin had a liverwort-like habit.

Bryophytes have been regarded as pioneer plants of deglaciated areas, but the preservation potential of these delicate plants in such sedimentary environments is very low. Therefore, the rare proglacial bryophyte fossils, such as those related to the CarboniferousPermian Gondwanic glaciation, are very intriguing (Barclay et al., 2013).

The bryophytes described herein record, in part, a vegetation of a cold climatic context during the Late Paleozoic Ice Age (LPIA, Parrish et al., 1986; Fielding et al., 2008).

They were found in three previously known outcrops (RicardiBranco et al., 2013) and a new one of the Itarare Group in the northern portion of the Paraná Basin (State of São Paulo, southeastern Brazil, Western Gondwana). These elements were preserved in association with megaspores.

The only non-glacial bryophytes of the Paraná Basin are recorded in a single outcrop of the Guadalupian Teresina Formation (Cristiano-de-Souza et al., 2012).

\section{Regional Geology and Paleontology}

The Paraná Basin (s.l.) encloses a large intracratonic syneclise in central-southern South America that was directly connected to the Chaco Basin (Argentina and Paraguay) and linked by seaways and/ or continental environments to the Cape-Karoo Basin (South Africa) and the Huab Basin (Namibia) (Milani and DeWitt, 2008). The Ordovician to Cretaceous sedimentary fill is divided into six depositional sequences (Milani et al., 2007), of which the Carboniferous-Permian interval (Supersequence Gondwana I), 1.5-2.4 km thick, comprises the Itararé, Guatá and Passa Dois groups (Fig. 1) (Milani et al., 2007; Bocardi et al., 2009). During this time, a probable clockwise rotation and northward movement of the Gondwana plate, as well as other global changes, caused a shift from a cold to a warm semi-arid climate in the Paraná Basin (Milani and DeWitt, 2008).

The Itararé Group encompasses one of the most expressive records of the Late Paleozoic Ice Age - LPIA in Southwestern Gondwana (Castro, 2004). According to palynological data (Souza, 2006; Souza et al., 2010) and the radiometric ages of overlying post-glacial strata (Rio Bonito Formation) (Souza, 2006; Holz et al., 2010), the deposition of the Itarare Group began in the Moscovian (Pennsylvanian) and ended in the Sakmarian (Cisuralian).

This unit is characterized by a great variety of lithofacies: claystones, sandstones, conglomerates, diamictites, varvites, turbidites, and thin coal seams, which formed in marine, coastal and

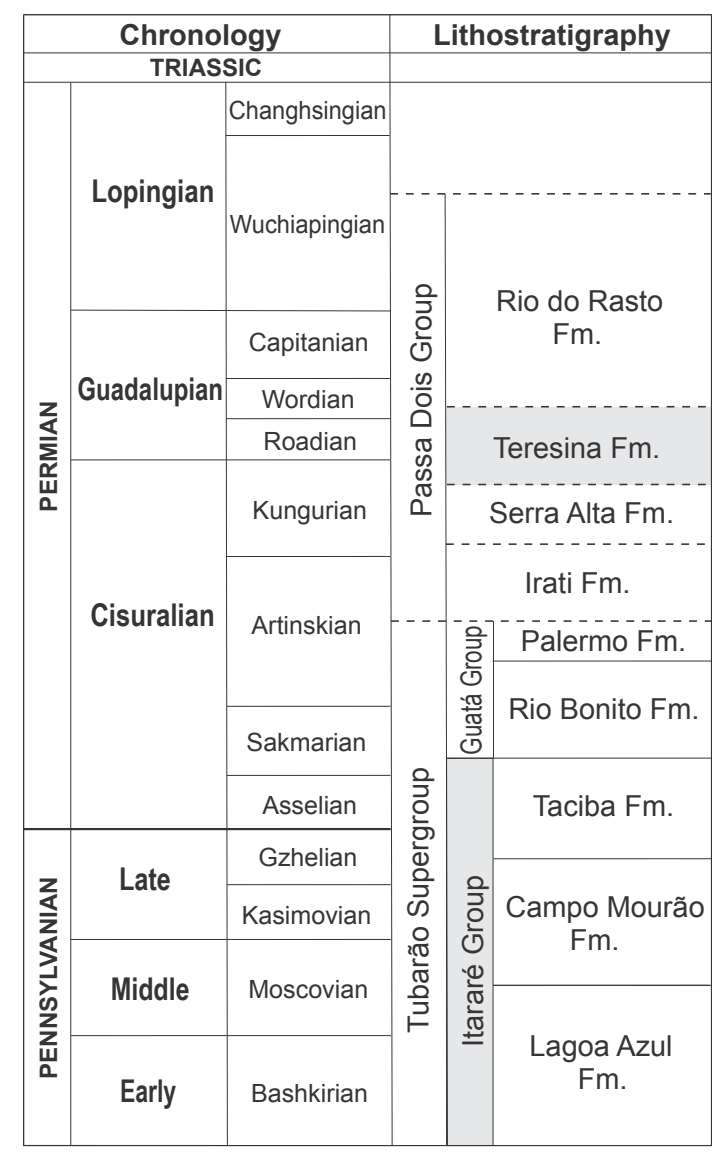

Fig. 1. Cronostratigraphy of the Paraná Basin during Gondwana 1 Supersequence (Milani et al., 1998). Ages of the Tubarão Supergroup according to Holz et al. (2010) and Passa Dois Group by Ferreira-Oliveira and Rohn (2010). Gray-coloured lothostratigraphic units contein bryophyte records.

continental environments under glacial, proglacial, and interglacial conditions (Rocha-Campos et al., 2008). A different interpretation is that almost all of the deposits represent deglaciation sequences (ice-retreat depositional tracts in stratigraphic sequences), and only small intercalated intervals may correspond to ice-advances (Vesely and Assine, 2006). Several fossils, such as brachiopods, mollusks, foraminifers, insects, fishes, and plants, are recorded in the Itararé Group. The marine fossils indicate that the paleoenvironments were mostly marine (Vesely and Assine, 2006; RochaCampos et al., 2008), but the origin of some rocks remains controversial (Rocha Campos et al., 2008). The most important vascular plant occurrences are associated with coally beds in the states of Rio Grande do Sul and São Paulo, which are likely related to interglacial intervals (Bernardes-de-Oliveira et al., 2005). The youngest interglacial interval has the first elements of the Glossopteris Flora (Rösler, 1978; Rohn et al., 2000).

In the northeastern portion of the Paraná Basin (State of São Paulo), where the studied fossils were collected, the Itararé Group is exposed in a narrow NE-SW strip, although it reaches its greatest thicknesses in this region (approximately $1300 \mathrm{~m}$; Vesely and Assine, 2006). The studied fossiliferous beds occur in the lower part of the group, only a few meters above the Precambrian basement, but the lower boundary of the unit is irregular because of glacial erosion. The depositional basin was a semi-isolated glacial inlet or estuary with salinity controlled by sea-level change (Rocha- 
Campos et al., 2008). Bergamaschi et al. (2016) worked in the regions of Salto and Itu but was a little distant from the Salto 1 and Salto 2 outcrops, and no rhythmites or fossil plants were recorded.

The Guatá Group, which was deposited after the Itararé Group, has slightly thicker coal beds and more abundant and diversified plant fossils of the Glossopteris Flora, but no bryophytes had been found to date. The succession represents early Permian (Souza, 2006) fluvial, deltaic, coastal and marine environments in a predominantly deepening upward trend that were probably under the influence of humid and gradually warmer climates (see the revision in Holz et al., 2010).

The Passa Dois Group is divided into the Irati, Serra Alta, Teresina and Rio do Rasto formations, which roughly document the transition from a carbonatic-siliciclastic epeiric sea (with mesosaurs) to semiarid continental environments, probably from the Kungurian (Cisuralian) to the Wuchiapingian (Lopingian) (see the revision in Holz et al., 2010). Several plant megafossils are known in numerous locations, but bryophytes were only found in a single outcrop of the Teresina Formation in Rio Preto Quarry near Irati, State of Paraná (Cristiano-de-Souza et al., 2012). This formation is mainly characterized by interlaminated dark shales/argilites and very fine sandstones with flaser/wavy/lenticular bedding, bioturbation and, commonly, mud cracks. These predominantly pelitic facies are arranged in cyclic upward-coarsening successions (usually a few meters thick) including thin intercalations of coquinites, carbonate mudstones, grainstones (commonly oolithic), microbialite beds and fish bone beds. In general, the paleoenvironment was a large very shallow interior sea (i.e., epeiric sea) influenced by storms and climatic oscillations from humid to arid, presenting low to high water salinities, respectively (Rohn, 2001, 2007; Rohn and Fairchild, 2015).

\section{Location of the outcrops, materials and methods}

\subsection{Fossiliferous outcrops and studied samples}

Two bryophyte and megaspores occurrences of the Itararé Group are located in the Municipality of Campinas, and the other two are in the Municipality of Salto, approximately $34 \mathrm{~km}$ away, in the central region of the State of São Paulo (Figs. 2-4). Considering that the previously known outcrops are important for the descriptions, their locations are provided again. This information, as well as the location of the new bryophyte occurrence, namely, Salto 2 , and the samples described here are as follows:

- Salto 1 outcrop: km 101.7 of the SP-75, Prefeito H. Steffen Highway, Salto Municipality (47 $19^{\prime} 28.74^{\prime \prime}$ W/23 $11^{\prime} 49.34^{\prime \prime}$ S). Megaspore sample CP1/508

- Salto 2 outcrop: near the Eucatex Industry, within the urban area of Salto ( $\left.47^{\circ} 17^{\prime} 5.91^{\prime \prime} \mathrm{W} / 23^{\circ} 12^{\prime} 42.21^{\prime \prime}\right)$. Bryophyte samples CP1/440-449, 450-505; megaspore samples CP1/ 473, 496-500, 502-504.

- Delta Landfill, Campinas Municipality ( $47^{\circ} 09^{\prime} 00.57^{\prime \prime} \mathrm{W} / 22^{\circ}$ $54^{\prime} 47.22^{\prime \prime}$ S). Megaspore samples CP1/509 to 537, 539, 542, 546, 547, 550, 552, 555 to 559, 562 and 563.

- $\mathrm{Km} 96$ of the Bandeirantes Highway (47 $07^{\circ} 56.96^{\prime \prime} \mathrm{W} / 22^{\circ} 55^{\prime}$ $15.40^{\prime \prime} \mathrm{S}$ ), which now corresponds to $\mathrm{km} 6.5$ of the Adalberto Panzan Highway, Campinas Municipality.

The samples are housed in the Repository of Paleontology of the Geosciences Institute of UNICAMP under their Paleobotanical Scientific Collection codes (CP1 code).

The Guadalupian bryophyte outcrop of the Paraná Basin is a quarry called Rio Preto, which is located at km 98 of the PR-364, $10 \mathrm{~km}$ south from the Irati urban center and $4 \mathrm{~km}$ north from Rio
Preto District (50 $44^{\prime} 52.81^{\prime \prime} \mathrm{W} / 25^{\circ} 31^{\prime} 30.36^{\prime \prime} \mathrm{S}$ ).

\subsection{Methods}

Well-preserved carbonized megaspore exine of 28 samples from the Delta Landfill Outcrop was successfully recovered from the matrix after maceration in $50 \% \mathrm{HCl}$ for one hour. Unfortunately, it was not possible to recover epidermis from carbonified gametophytes. Other megaspore and gametophyte samples are preserved as impressions.

The equipment used in this study was a Zeiss Stemi 2000-C stereoscopic microscope with a coupled digital camera and, for the bryophyte sample (CP1/416) of the Salto 1 outcrop, a scanning electron microscope (SEM) with energy dispersive spectroscopy (EDS) to determine the elemental composition at selected points on the gametophytes. The samples were reduced in size and coated laterally with an epoxy resin to form the efficient vacuum during the SEM and EDS analyses.

The taxonomic classification of the bryophytes was based on common criteria cited in the bibliography (e.g., Goffinet et al., 2009), such as the shape of the phyllids, the disposition around the stem and the relative dimensions. Intraspecific variations in megaspores, as noted by Trindade $(1959,1962)$, were noted through detailed descriptions and measurements of more than a hundred specimens. The plant kingdom classification scheme proposed by Frey (2009) was followed.

\section{Results}

\subsection{Characterization of the bryophyte beds}

In the Itarare Group, the bryophytes (mainly gametophytes) occur as small fragments and are associated with megaspores, dispersed cuticles, and unidentified phytoclasts, and the types of fossilization are carbonization (compression) or mold (impression). Ricardi-Branco et al. (2013) proposed the species Dwykea araroii for bryophytes from the Salto 1, Bandeirantes Highway (including aff. Dwykea sp. in Amaral et al., 2004) and Delta Landfill outcrops.

The Delta Landfill and Bandeirantes Highway outcrops expose massive and laminated mudstones, rhythmites, siltstones and shales. At the second outcrop, the rhythmites are $8 \mathrm{~m}$ thick, and the bryophytes and megaspores were observed along this succession. Thick, deformed sandstones are stacked on the top. The rhythmites were interpreted as distal facies of fans on marine slopes formed under the influence of meltwater inflows (Souza Filho, 1986) or in shallow water (Amaral and Ricardi-Branco, 2004).

Souza et al. (2006) suggested that the palynological content associated with the macrofossils at the Bandeirantes Highway outcrop is equivalent to that of the Ahrensisporites cristatus Interval Zone (Late Bashkirian to Moscovian, according to Souza, 2006 the oldest palynozone of the Itararé Group.

The Salto 1 and Salto 2 outcrops, which are now almost completely covered, present diamictites, sandstones, conglomerates, breccia and rhythmites (composed of 1-2 cm-thick pairs of very fine sandstones grading to dark shales). The rhythmite at Salto 1, which bears rare dropstones (Longhim et al., 2002), represents typical turbidites formed in a proglacial context, and its upper $0.5 \mathrm{~m}$ is in an inverse position (upside down) and brecciated close to its contact with an overlying massive, $8 \mathrm{~m}$-thick sandstone. The inverted bed was certainly still plastic when a glacial thrust, or another glaciogenic process, folded it like an atectonic nappe. In addition to relatively abundant bryophytes and megaspores, the rhythmite at Salto 1 contains a palynological assemblage of approximately 60 pollen and spore species that, unlike the premise, are partly indicative of not strictly cold climates (Longhim et al., 


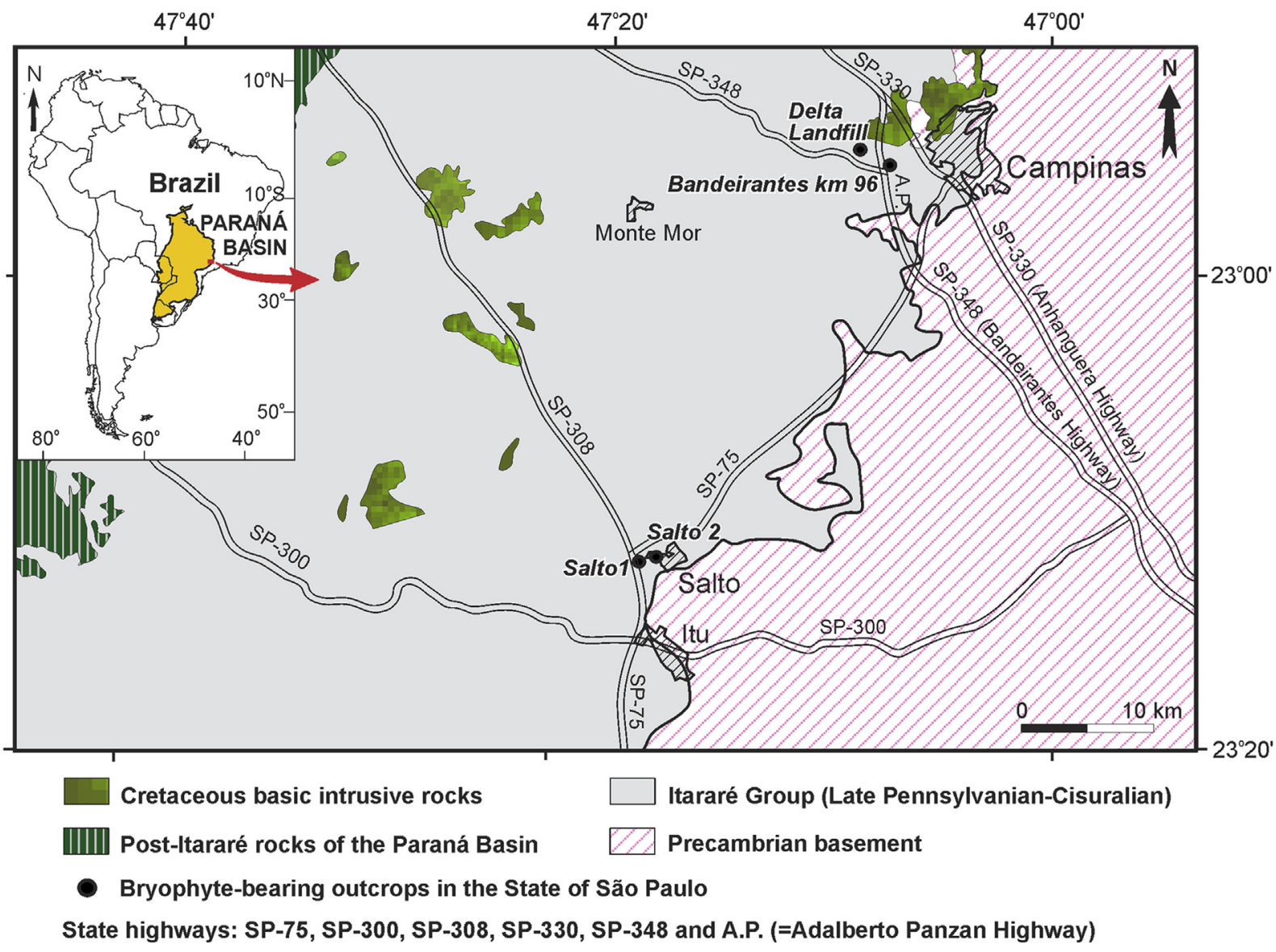

Fig. 2. Geologic map of the region of Campinas and Salto, State of São Paulo, Brazil (according to Almeida et al., 1981) and location of the fossiliferous outcrops.

2002). The palynoflora includes Deusilites tenuistriatus (whose affiliation is rather uncertain) and Botryococcus algae; no acritarchs were recognized (Longhim et al., 2002). It is consistent with the Crucisaccites monoletus Interval Zone, which is ascribed to the Moscovian-Kazimovian (Pennsylvanian) according to Souza (2006). At the Salto 2 outcrop, reported here for the first time, the fossils occur in an approximately 0.5 -m-thick, weathered, light yellow to gray pelite.

The bryophytes of the Teresina Formation of the Passa Dois Group, are restricted to a $1.8 \mathrm{~m}$-thick, light gray, massive siltite above giant mud cracks at the base of the quarry (Neves et al., 2011), and the gametophytes commonly occur in close parallel orientation in several levels. Cristiano-de-Souza et al. (2012) proposed two bryophyte genera and species: Capimirinus riopretensis and Yguajemanus yucapirus, which are associated with abundant charophyte oogonia of the genus Leonardosia (Porocharaceae Family) described by Faria et al. (2013). Dispersed lycophyte stems identified as Lycopodiopsis derbyi and structures that are probably related to strobilus bracts were also found in the siltite (Faria et al., 2009). This bed is overlain by meter-thick coarsening-and-thickening upward successions of bioturbated heterolithic shales/very fine sandstones with wavy bedding. The siliciclastic rocks are interrupted by a few decimetric carbonates in the form of a $0.5 \mathrm{~m}$ thick calcarenite composed of fragmented and complete bivalve mollusks, some allochthonous microstromatolites, other carbonate grains and silicified lycophyte microphylls (Neves et al., 2011).

Additional bryophytes in the Paraná Basin include Tallites sp., mentioned by Rigby (1968) and Mezzalira (1980) for the State of São Paulo. Because both species must be reviewed, they were not considered in the final discussion of this work.

\subsection{Chemical composition of the compressions}

The targets of the EDS analyses were selected according to visual differences, such as in color and texture. The spectra generated from the three selected points are represented in Fig. 5, and based on the graphs and tables, the high content of carbon (C) in the fossils suggests a latent process of carbonification. The presence of barite, which can very often be an indicator of a reducing environment (Bonny and Jones, 2008), is also clear.

\subsection{Systematic paleontology}

\subsubsection{Macrofossil remains}

Class Bryophyta Schimper, 1879.

Genus Dwykea Anderson and Anderson, 1985.

Dwykea araroii Ricardi-Branco et al., 2013.

Figs. 6 and 7 (1, 2, 7 and 8).

Material. CP1/440, 441, 447-453, 455, 462, 469-472, 487-492, 496-498, 503 and 505.

Stratigraphic and geographic location. Itararé Group at the Salto 1, Salto 2 (not previously reported), Delta Landfill and Bandeirantes Highway outcrops.

Description. Gametophytes with erect stems greater than $5.8 \mathrm{~mm}$ in length and 0.27 to $1.12 \mathrm{~mm}$ in thickness. Erect-patent phyllides, with phyllotaxis in spiral, more tightly closed near the apex. Lanceolate phyllides with entire margins, amplexicaul bases, and acute tips. Average length of $2.81 \mathrm{~mm}$ and width at the base of 


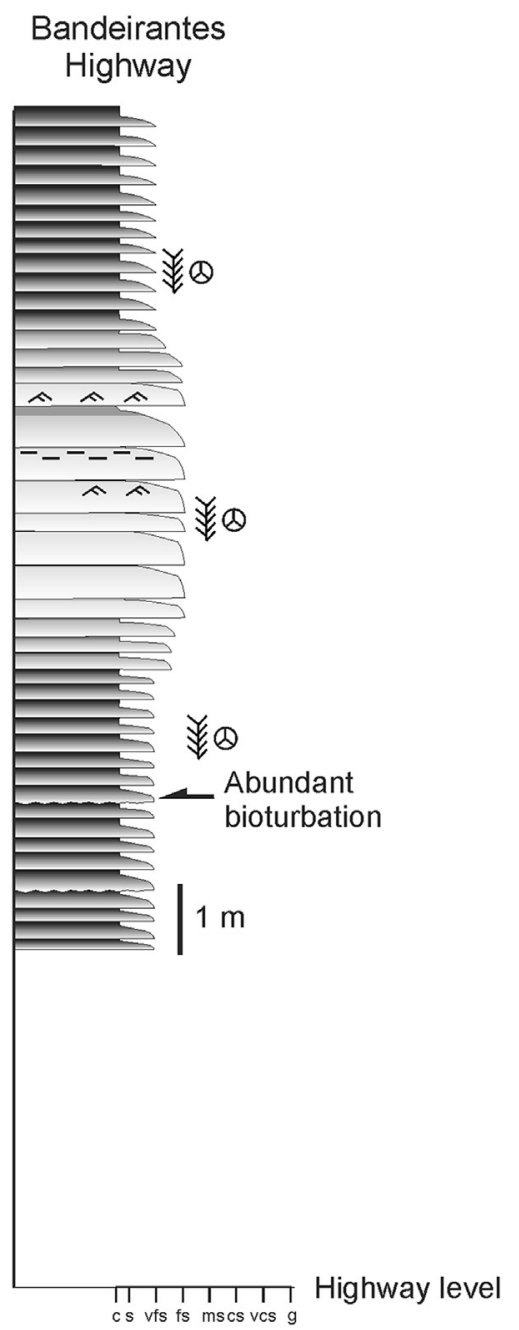

Rhythmites (very fine
sandstones to shales)
Medium/ coarse-grained
sandstones
B Breccia of rhythmite clasts
D Ripple drift cross-lamination
\& Bryophytes and megaspores

\section{Salto 1}

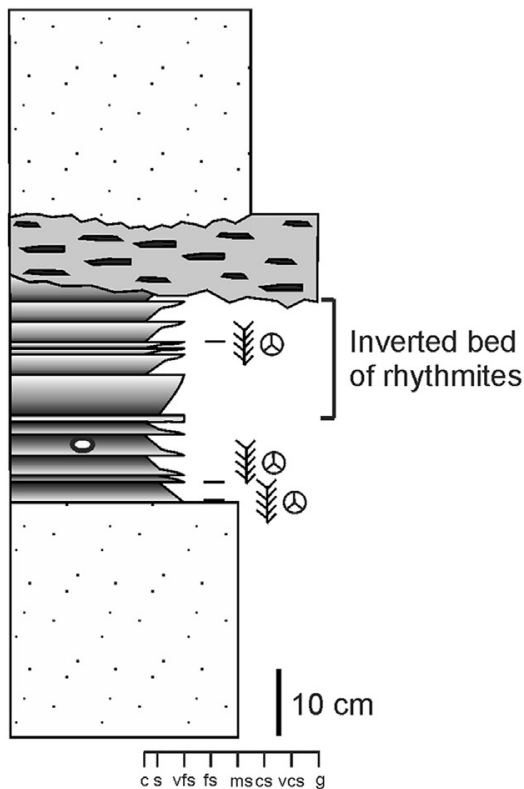

Fig. 3. Columnar sections of the most important fossiliferous outcrops: km 96 of the Bandeirantes Highway and Salto 1.

$0.33 \mathrm{~mm}$ and $0.05 \mathrm{~mm}$ at the tip.

Discussion. All of the described gametophytes can be assigned to the Gondwanic genus Dwykea Anderson and Anderson 1985 that was established for specimens of the Dwyka Group (Karoo Basin, South Africa). The Dwyka Group, as with the Itarare Group, records Pennsylvanian to Cisuralian glacial and interglacial deposits (Milani and DeWitt, 2008). The studied gametophytes bear wider and shorter phyllides than Dwykea goedehoopensis from Africa (comparisons in Table 1), which reinforces the previous justification for the proposed species D. araroii Ricardi-Branco et al., 2013. The newly analyzed specimens present slightly wider phyllides than those in Ricardi-Branco et al. (2013) (0.3 mm instead of $0.2 \mathrm{~mm}$ ), and the stems are generally more fragmented, not reaching half the length of some previously described specimens. The new fossil material does not include sporophytes.

The only possible pleurocarpic sporophyte belongs to the apparently immature specimen found in association with gametophytes from the Bandeirantes Highway outcrop, originally identified as aff. Dwykea sp. (Amaral et al., 2004) and synonymized with D. araroii in Ricardi-Branco et al. (2013), with a $0.6 \mathrm{~mm}$-long and $0.04 \mathrm{~mm}$-wide seta holding a $0.2 \mathrm{~mm}$-long and $0.08 \mathrm{~mm}$-wide capsule.

\subsubsection{Microfossil remains}

Anteturma Sporites Pant, 1962.

Turma Triletes (Reinsch) Potonié and Kremp, 1954.
Supraturma Lagenotriletes Potonié and Kremp, 1954. Subturma Gulati Bharadwaj, 1957.

Genus Sublagenicula Dybová-Jachowicz et al., 1979. Sublagenicula brasiliensis (Dijkstra, 1956) Dybová-Jachowicz et al., 1979

Fig. $7(3,4,5$, and 6).

Material. Lateral and proximal-distal compressions, one hundred thirteen (113) specimens in CP1/473, 496-500, 502-504, 508 to $537,539,542,546,547,550,552,555$ to 559,562 and 563.

Stratigraphic and geographic location. Itararé Group, Salto 1 and 2 and Delta Landfill outcrops.

Description. Trilete, subgulate megaspores, prolate in lateral compression and oval in proximal-distal compression. Straight trilete rays. Well-defined arcuate ridges. Confluence of trilete rays with arcuate ridges sometimes marked by small triangular auriculae. Ornamentation of the psilate at contact area and psilate to scabrous in distal area.

Dimensions.

Polar view: Length 1060-1444 $\mu \mathrm{m}$ and width 854-1400 $\mu \mathrm{m}$. Trilete ray 540-670 $\mu \mathrm{m}$. Arcuate ridge $452-934 \mu \mathrm{m}$.

Equatorial view: Length $956-1180 \mu \mathrm{m}$ and width $502-1553 \mu \mathrm{m}$. Trilete ray $489-801 \mu \mathrm{m}$. Arcuate ridge $322-1010 \mu \mathrm{m}$.

Discussion. The described specimens, according to their gula, trilete ray, distal area exine ornamentation, contact area, and dimensions, are similar to Sublagenicula brasiliensis recorded in monospecific megaspore assemblages, which is the most abundant 

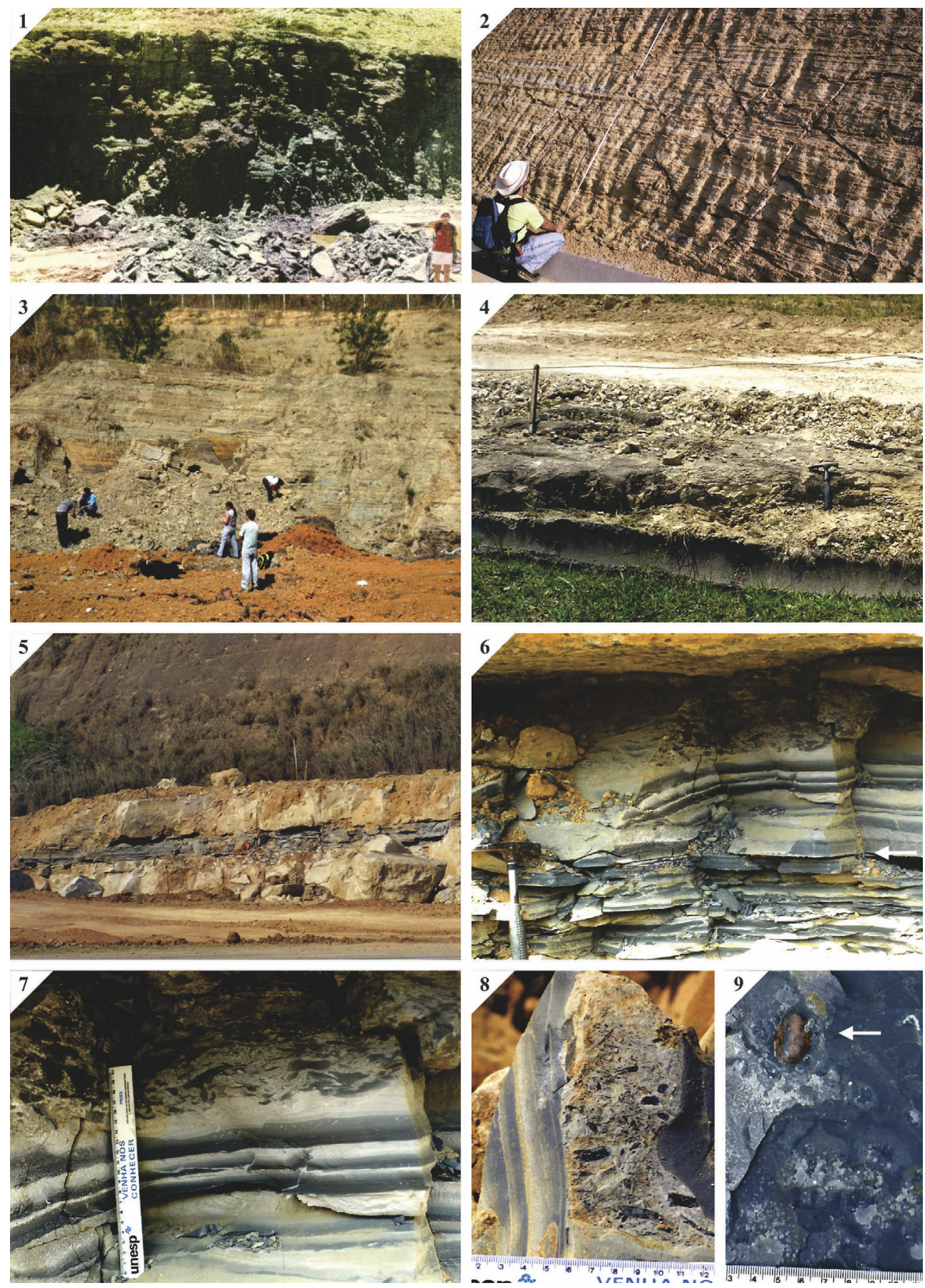

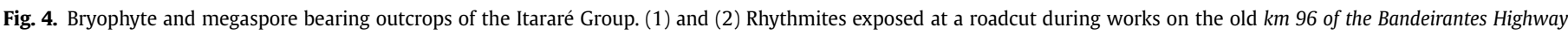

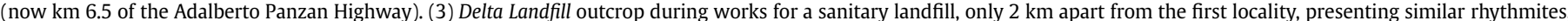

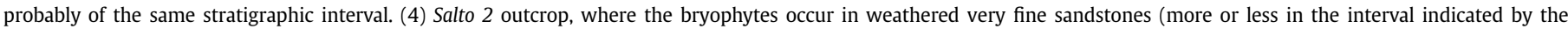

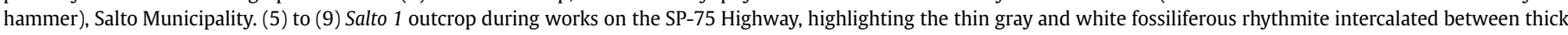

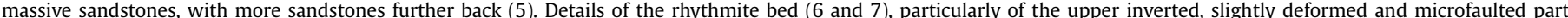

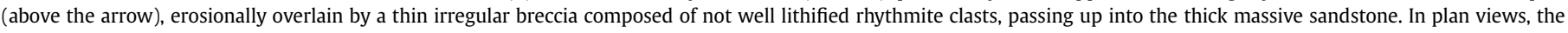
rhythmite shows carbonized plant fragments (8) and a dropstone (9, arrow).

taxon of the Itararé Group in the State of São Paulo at Monte Mor, Buri and at km 96 of the Bandeirantes Highway Outcrop (Trindade, 1959, 1970; Amaral and Ricardi-Branco, 2004; Mune and Bernardes de Oliveira, 2007).

This species was also found in the states of Paraná (Arai and Rösler, 1984; Ricardi-Branco et al., 2002), Santa Catarina (Dijkstra, 1956; Trindade, 1959; Pant and Srivastava, 1962), and Rio Grande do Sul (Dijkstra, 1956; Trindade, 1962, 1964, 1966; Pant and Srivastava, 1962; Cauduro and Zigano, 1965; Marques-Toigo et al., 1975; Bortoluzzi and Veiga, 1981).

Outside of the Paraná Basin, this species has been recorded in the Upper Carboniferous of Argentina (San Rafael and Paganzo Basins, Garcia, 1995) and the Permian strata of the Tepuel-Genoa Basin. On the African continent, it has been reported in the Lower 


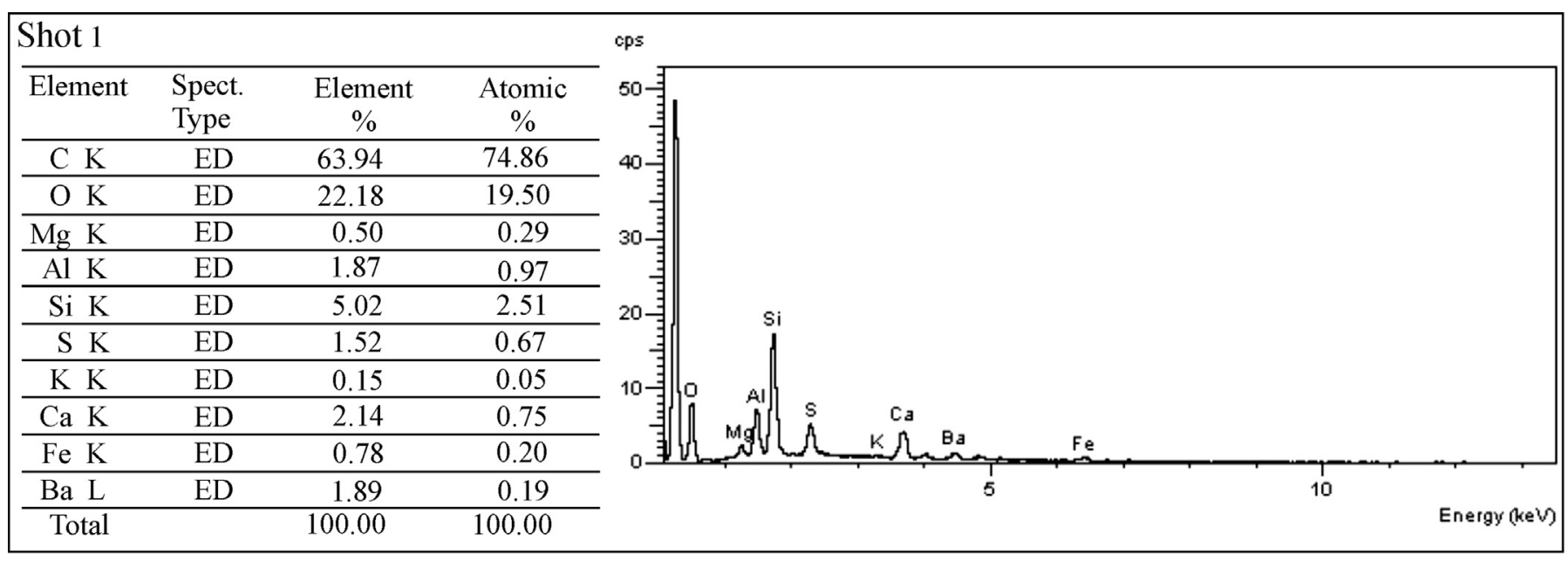
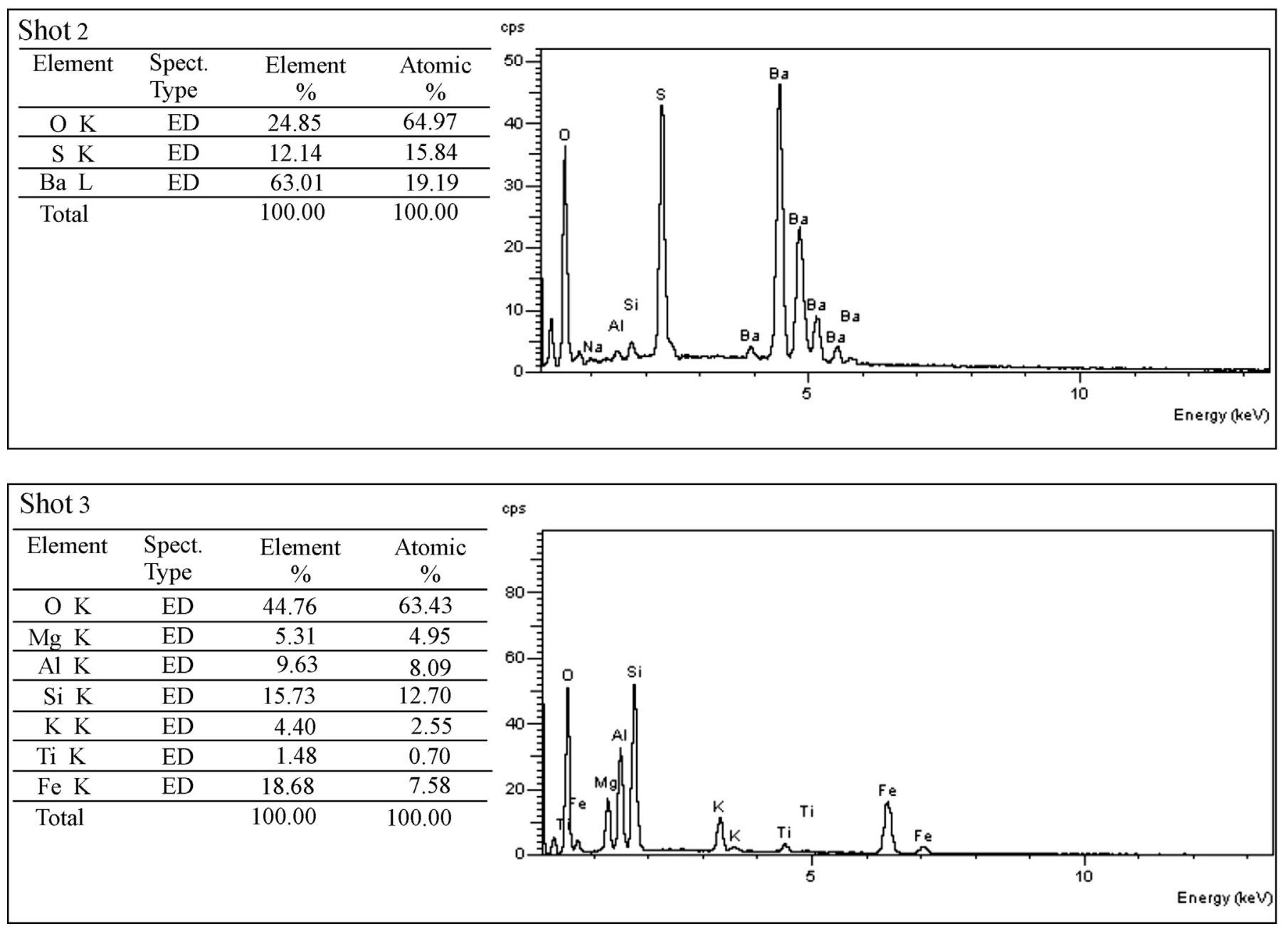

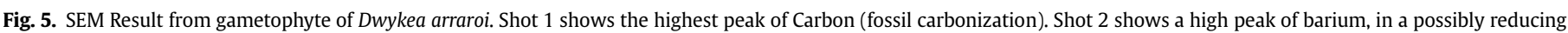
environment, and Shot 3 indicates the mineralogical composition of the rocky matrix.

Carboniferous of Egypt and Chad, in the Visean of Nigeria, and in the Namurian of Algeria and western Libya. It has also been found in the Lower Permian of the Democratic Republic of Congo (Dybová-Jachowicz et al., 1987; Glasspool, 2003) and South Africa (Glasspool, 2003).

\section{Discussion of the results}

Sousa Filho (1986) interpreted the fossiliferous rhythmites of the Itararé Group at the Bandeirantes Highway outcrop as turbidites that originated from glacial meltwater discharges and deposited in 

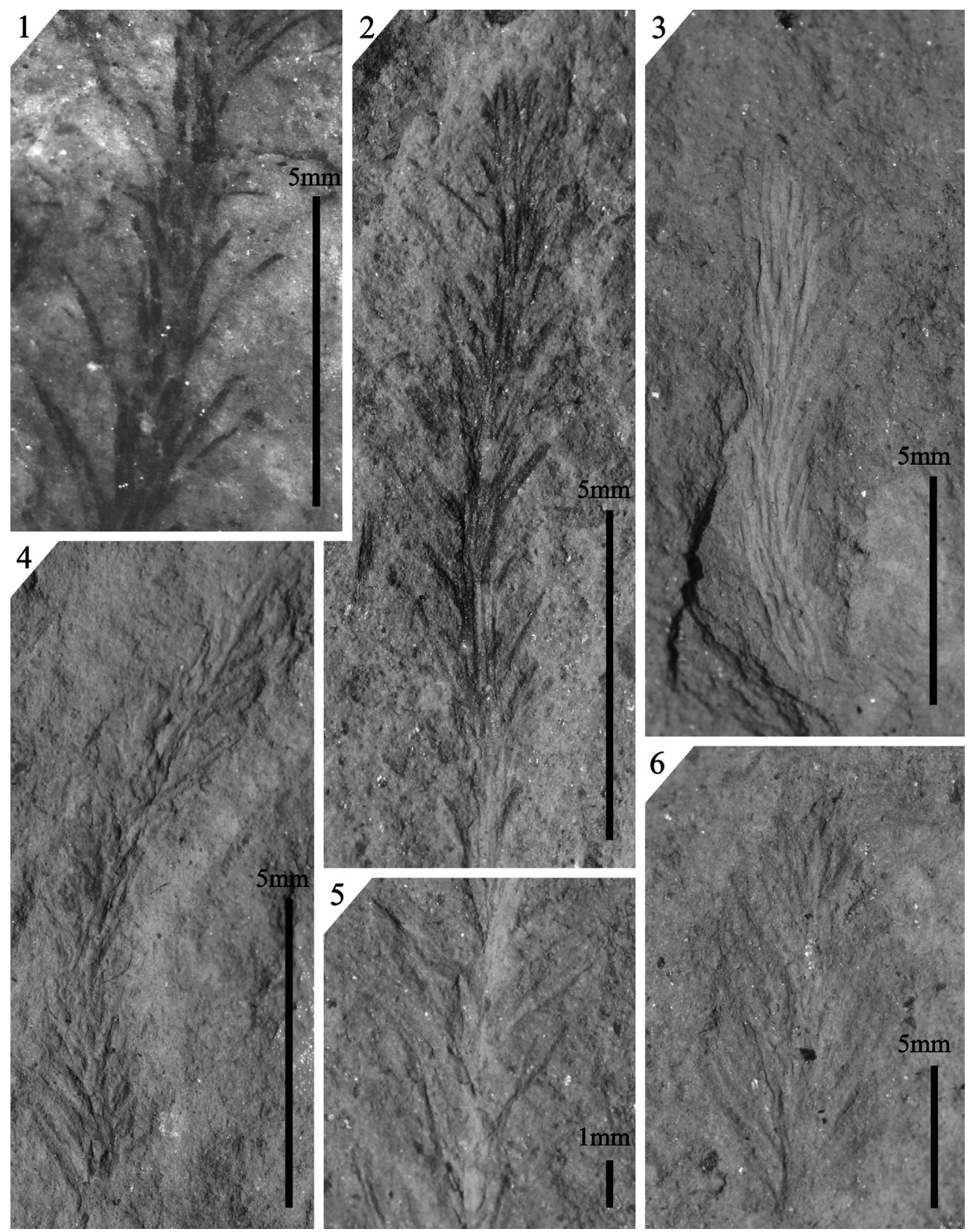

Fig. 6. Gametophytes of Dwykea araroii. (1), (2), (3), (4), and (6) Gametophytes with phyllotaxis in spiral, lanceolate phyllides, with amplexicaulis bases, and acute tips. Phyllides with phyllotaxis in spiral. Salto 1 Outcrop (1, CP1/244) and Salto 2 Outcrop (2. Sample CP1/244; 3. Sample CP1/447d, 4. Sample CP1/441; 5. Sample CP1/487, and 6. Sample CP1/440). (5) Note more condensed phyllides near the apex.

relatively deep and anoxic bathyal conditions. Vesely and Assine (2006) noted that the topographic gradients of the Paraná Basin were, in reality, low, but they also interpreted fine-grained particles, such as rhythmically laminated silt-clay couples, as representing "distal" glaciomarine environments during deglaciation and the gradual rise of the relative sea level. However, the high abundance of the bryophytes, their good preservation without strong fragmentation, the presence of a very fragile probable lateral sporophyte and the abundant megaspores evidence very proximal and shallow depositional settings instead (cf. bryophyte taphonomy in Bomfleur et al., 2014). The plants must have not been transported as bedload but in slow, fluctuating water flows and deposited in very calm conditions. Therefore, the term "distal" must here be considered to mean "not close" to outwash fans in front of retreating glaciers and relatively near the plant community. The presence of dropstones in the rhythmite at Salto 1 and the inverted position of the upper part of this bed indicate that icebergs and glaciers were penecontemporaneous to the bryophyte vegetation and reinforce the interpretation of a predominantly cold climate.

The presence of Botryoccocus and the apparent lack of acritarchs in the rhythmite of Salto 1 (Longhim et al., 2002) does not necessarily point to a lacustrine paleoenvironment; a palynofacies analysis is recommended.

Bomfleur et al. (2014) emphasized that the preservation of bryophytes usually requires rapid burial to inhibit chemical decay and destruction by organisms, but this premise can only partly be extrapolated to the Itararé Group. Firstly, it is necessary to bear in mind that plants lying on the floor of cold water environments are 

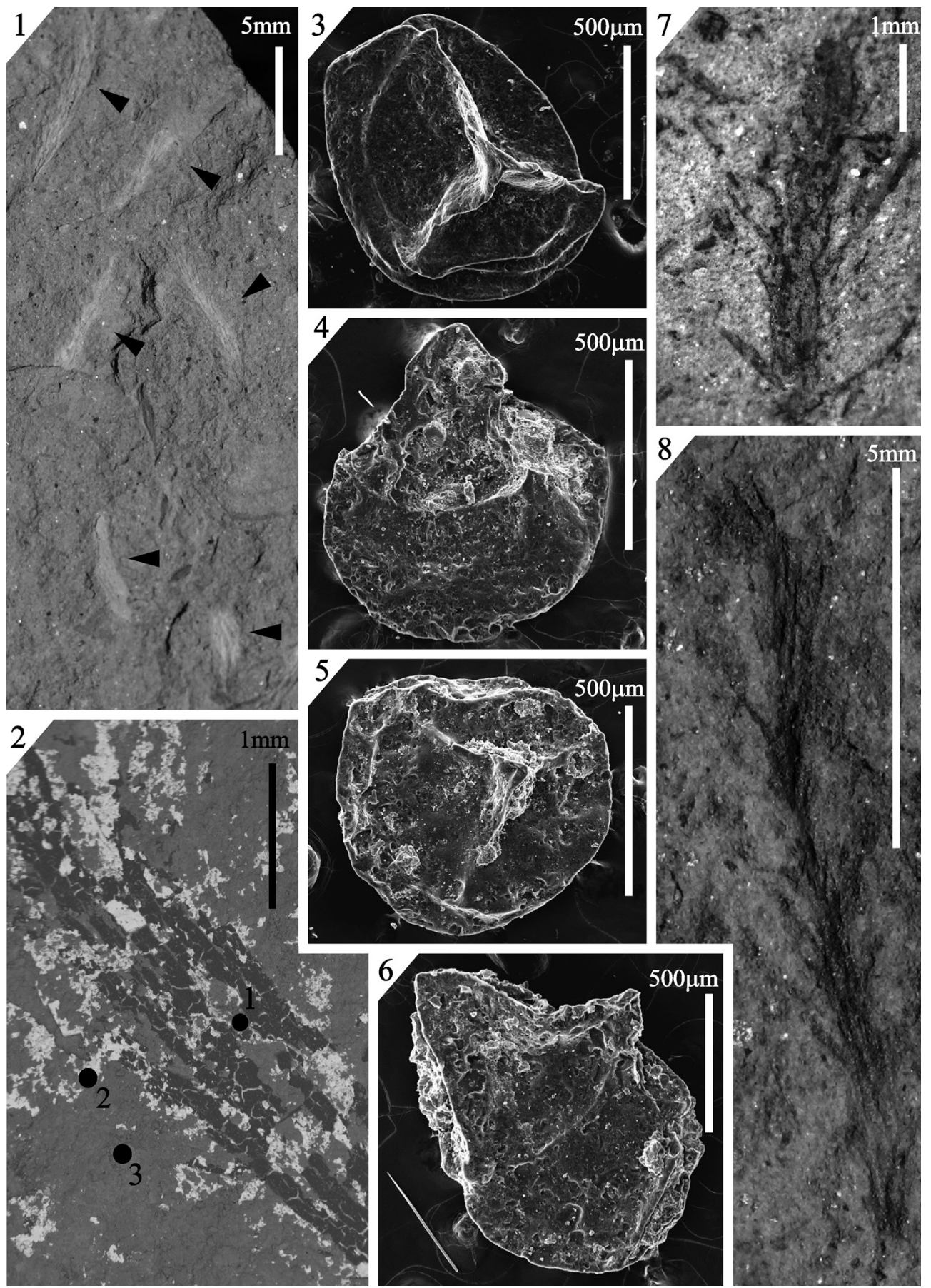

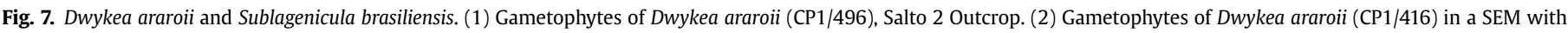

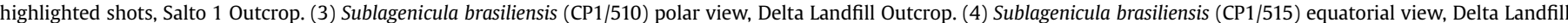

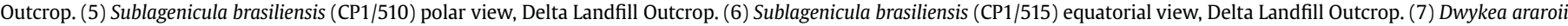
(CP1/556), Delta Landfill Outcrop. (8) Dwykea araroii (CP1/497), Salto 2 Outcrop.

less prone to destruction or degradation by scavengers and decomposers because these organisms are less active at low temperatures. If the water of the depositional environment had been warm, the presence of carbon and barite in the studied fossils, or simply the compressions per se, would attest to depleted dissolved oxygen in the lower part of the water column. However, under cold conditions, the produced organic matter could have been insufficient to cause anoxic conditions, so the water circulation (controlling the dissolved oxygen) was possibly more effective depending on the temperatures of the inflowing melt-water, salinity, etc. The coalification of macrodetritus does not necessarily indicate depleted oxygen in the depositional site but rather a low percolation rate of oxygenated waters in the plant-bearing deposit (as argillaceous muds), thus preventing plant degradation (Gastaldo, 1988). Therefore, the preservation of the bryophytes in the Itarare Group must have been enhanced by low temperatures and a more or less rapid, but not quite catastrophic, burial (compare with the statement of Bomfleur et al., 2014 about rapidly buried bryophytes 
Table 1

Comparison of the described samples of Dwykea araroii and Dwykea Anderson and Anderson (1985).

\begin{tabular}{lll}
\hline Morphological features & Dwykea in Dwyka group, South Africa & Dwykea araroii of the Itararé group (this study) \\
\hline Stem length & $>25 \mathrm{~mm}$ & $>5.8 \mathrm{~mm}$ \\
Leaves length $\times$ width) & $5.0 \mathrm{~mm} \times 0.15 \mathrm{~mm}$ & $3.0 \mathrm{~mm} \times 0.3 \mathrm{~mm}$ \\
Leaf Apex & Acute & Acute \\
Phyllotaxis & & Helicoidally \\
Costa & Preserved & Preserved \\
Gametophyte & & Pleurocarpic? \\
Sporophyte & & \\
\hline
\end{tabular}

in a fluvial depositional system). The rhythmites at least evidence repetitive (periodic?) embedding events of the plants.

Taking into account the likely gentle taphonomic factors in the origin of the bryophyte beds (such as the low transport of the plants, almost no selection by floatage, etc.), the monotonous associations of Dwykea araroii along with the monospecific (Salto 1-2 and Delta Landfill outcrops) or poorly diversified megaspore assemblages (Bandeirantes Highway outcrop) reflect low plant diversities in the source vegetations. The most important controlling factor of the small number of species must have been the cold climate.

It is important to note that the palynological assemblage of the Salto 1 rhythmite may be assigned to the flora of a warmer climate (Longhim et al., 2002), but wind or water (or even glaciers, in part) may have easily transported or reworked spores and pollen grains from distant warmer source areas to the depositional site.

The bryophyte communities represented in the Itarare Group could have belonged to tundra-like biomes in coastal environments, so the subsoil (a few decimeters below the surface) may have been permanently frozen, as in the typical tundra biomes of Antarctica where bryophytes have been the dominant vegetation components since the Miocene (Lewis et al., 2008; Ochyra et al., 2008; Désamoré et al., 2012). As typical opportunistic elements, this vegetation could have immediately colonized exposed areas after the retreat of glaciers. The true interglacial successions, formed at times of considerable climate amelioration, include much richer plant beds as well as coal (Bernardes-de-Oliveira et al., 2005).

The presumed cold climate probably implied low (liquid) water availability for the bryophyte beds, at least during the winter. The poikilohydry and the tolerance to desiccation of bryophyte gametophytes (Mishler and Kelch, 2009) meant a survival advantage

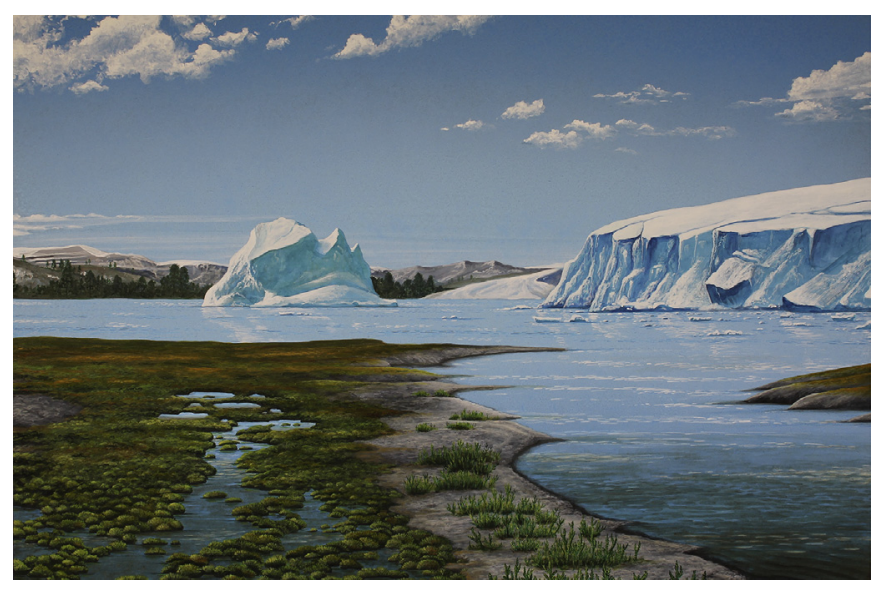

Fig. 8. Reconstruction of the landscape where the bryophytes and lycopods lived according to the studied fossils of the Itararé Group at Campinas and Salto, State of São Paulo. under water deficit (Fig. 8).

Megaspores assigned to the genus Sublagenicula were probably produced by lycophytes (e.g., Brasilodendron; see Glasspool, 2003), but considering that this genus, particularly S. brasiliensis, has a large stratigraphic range (Pennsylvanian - Cisuralian) and apparently lived in distinct paleoclimates (from cold to temperate) and diverse paleoenvironments (marginal swamps, flood plains, etc.), it is difficult to interpret the characteristics of the mother plant. Similar megaspores were perhaps produced by distinct lycophytes. In the idealized community reconstruction in Fig. 8, the producing Sublagenicula brasiliensis plant is represented by an herbaceous lycophyte, which is consistent with rapid growth during the milder seasons of a cold climate context. Mishler and Kelch (2009) commented that Lycophyta also included tolerant species with respect to hydrological constraints, and this interpretation can be extended to the producing plant of Sublagenicula brasiliensis.

In terms of the paleogeographic and temporal/stratigraphic distribution of the bryophytes, Catuneanu et al. (2005) commented that Dwykea occurs in association with proglacial conditions in the Karoo Basin. Hence, this genus was at least successful at dispersing in the immense Western Gondwana proglacial terrains during the Pennsylvanian. Although the known bryophyte occurrences are still few, the low diversity and the large geographic distribution (and also, apparently, the ample stratigraphic range) corroborate the interpretation that Dwykea was an opportunistic element.

The megaspore Sublagenicula occurs from Argentina to South Africa in the Pennsylvanian - Cisuralian. Based on the spatial and temporal distribution of S. brasiliensis, Piérart $(1975,1981$; 1984) noted the possibility that this species has been one of the "transgressive megaspores", along with Setosisporites furcatus, that were typical of the marginal areas of glaciers during the Carboniferous and that established in coastal environments with the Glossopteris Flora during the Permian under inter- or post-glacial transgressive conditions. According to the Sublagenicula record in the coalbearing Rio Bonito Formation of the Paraná Basin, the respective lycophytes were relatively flexible plants with respect to the climate, from cold and dry glacial conditions to temperate/warm and humid conditions. However, they supposedly have not reached the Northern Floras, perhaps because they were not able to invade areas with ecologically similar plants in addition to possible geographic (e.g., Hercynian Mountain Range) and climatic barriers (e.g., an arid belt in low latitudes; Capretz and Rohn, 2013). Sublagenicula have also not been recorded in younger stratigraphic levels of the Paraná Basin, which are related to warmer and dryer climates. However, this absence can be absolutely taphonomic considering that small lycophyte stems and microphylls are common in the Teresina Formation (Faria et al., 2009; Faria and RicadiBranco, 2010), and some not-yet-studied but reported megaspores have been found in this formation in the Western part of the basin (Dharani Sundaran, Federal University of Mato Grosso, oral communication).

Similarly, the lack of bryophytes in the Rio Bonito Formation may be a taphonomic artifact. Mosses were surely abundant and 
diversified in the shaded, warm and humid areas of the understory of the Glossopteris vegetation, but they must have been destroyed by exposure to chemical and microbial decay as well as during transport and mixing with more resistant vascular plants. For example, Bomfleur et al. (2014) found only very small bryophyte fragments ( $<1 \mathrm{~cm}$ long) mixed with other fossil phyllids in Triassic floodplain and crevasse-splay deposits in Antarctica and commented that other probable bryophytes occur as abundant but unrecognizable very small organic fragments.

In the stratigraphic succession of the Paraná Basin, it is significant that bryophytes reappear in one bed of the Teresina Formation, and the fact that the bryophyte genera of this formation are distinct from Dwykea is not surprising because they were separated by a long time span and lived under different climate conditions. The discovery of these bryophytes was made possible by the good exposure of the rock in a quarry, but luck during a fieldtrip could not have been the only favorable factor. The bryophytes, which were associated with one species of carophyte oogons as well as very rare, small but also monospecific lycophyte stems and not-yetdescribed rare strobili bracts, were probably deposited in a very proximal and calm environment, such as a temporary pond, without the input of vascular plants that should have masked or hidden the delicate bryophytes. According to this hypothesis, the fossil assemblage was derived from a vegetation mostly composed of bryophytes and rare lycophytes that was perhaps controlled by a water-saturated soil, very unstable environmental conditions and/ or scarce freshwater, and this, in turn, could have been controlled by low pluviosity. The lycophytes and bryophytes, like modern mangroves, were probably hydro-hygrophyllous and tolerant to slightly saline water (Garbary et al., 2008; Faria et al., 2009). According to the epeiric sea model interpreted for the Teresina Formation (Rohn and Fairchild, 2015), the very low floor gradients of the basin defined a huge and wide marginal area that was sometimes totally exposed and sometimes totally flooded. At times of exposition, the slightly depressed parts of the floor were transformed into tiny temporary ponds, which could have been fringed by the bryophyte and lycophyte vegetation and colonized by charophyte algae. The vascular plants of the true terrestrial regions with normal soils lived far from the bryophytes and thus are only scarcely represented in the formation. As in the glacial Itararé Group, the bryophyte vegetation recorded in the Teresina Formation can be classified as an opportunistic community.

\section{Conclusions}

As shown here, Permo-Carboniferous bryophytes are rare fossils, and nearly all records in Gondwana are limited to the Paraná Basin and were the result of recent research. The present study increased the number of bryophyte occurrences in the Itararé Group to four, and palynological analyses positioned the fossil beds in distinct stratigraphic intervals within the Carboniferous part of this unit. The fossil assemblage of the new outcrop, as with those in earlier studies, is composed of the single bryophyte species Dwykea araroii Ricardi-Branco et al. and the megaspore Sublagenicula brasiliensis (Dijkstra) Dybová-Jachowicz. The bryophytes are probably the oldest representatives of the Core Pleurocarps sensu Bell et al. (2007). S. brasiliensis was most certainly produced by lycophytes, and only the Bandeirantes Highway outcrop yielded other rare megaspores.

Based on the abundance and preservation of the fossils, their low diversity cannot be ascribed to taphonomic selection but probably to an original low-diversity tundra vegetation that was installed in coastal areas during glacier retreat in early interglacial intervals. Dwykea and the Sublagenicula producing plants were certainly opportunistic and not only tolerated the cold climate but also a relative (liquid) water deficit. In the Karoo Basin, where the genus Dwykea was proposed, these proglacial conditions were probably very similar. Bryophytes were not recognized in the more diversified plant assemblages that formed during the warmer interand post-glacial intervals, but this absence may be related to the low preservation potential of these plants. In contrast, Sublagenicula is represented in a greater stratigraphic range and in wider Gondwanic areas, which suggests that the respective lycophytes tolerated a broader scale of climates.

In the higher stratigraphic levels of the Paraná Basin as well as throughout Gondwana, the only preserved bryophytes were found in a single bed of the Guadalupian Teresina Formation and designated as Yguajemanus yucapirus and Capimirinus riopretensis by Cristiano-de-Souza et al. (2012). As the older glacial bryophytes, those of the Teresina Formation may also indicate a poorly diversified, opportunistic local vegetation, including monotonous hydrohygrophyllous dwarf lycophytes, that probably fringed small shallow ponds across the wide marginal areas of an epeiric sea.

\section{Acknowledgements}

The authors would like to thank Fapesp (Fundação de Amparo à Pesquisa do Estado de São Paulo - the São Paulo Foundation of Support to Research Work) for two research financial supports: Grant 97/03639-8 "Survey of the paleofloristic composition and succession of the Neocarboniferous- Eopermian (Tubarão Group) in the State of São Paulo" and Grant 2013/11563-6. "Integration of multisource data for the paleobotanical analysis of the Paraná Basin in the Carboniferous-Permian interval". The research was also funded by CNPQ (Conselho Nacional de Desenvolvimento Científico e Tecnológico - National Council for Scientific and Technological Development) 304805/2014-9 and doctoral grants. The helpful suggestions of reviewer William DiMichele, Regional Editor and one anonymous reviewer are also acknowledged.

\section{References}

Almeida, F.F.M. de, Hasui, Y., Ponçano, W.L., et al., 1981. Mapa Geológico do Estado de São Paulo. Escala 1:500.000. Secretaria da Indústria, Comércio, Ciência e Tecnologia. Instituto de Pesquisas Tecnológicas do Estado de São Paulo-IPT, PróMinério v.1 e 2, 126 p. (Publicação IPT 1184. Monografias 6).

Amaral, P.G.C., Bernardes-de-Oliveira, M.E., Ricardi-Branco, F., Broutin, J., 2004. Presencia de Bryopsida fértil en los niveles Westfalianos del Subgrupo Itararé, Cuenca de Paraná. Bras. Trop. Bryol. 25, 101-110. http://dx.doi.org/10.11646/ bde.25.1.12.

Amaral, P.G.C., Ricardi-Branco, F., 2004. Ocorrência de megásporos no Carbonífero (Subgrupo Itararé) na porção NE da Bacia do Paraná, Estado de São Paulo. Rev. Bras. Geol. 34, 253-262.

Anderson, J.M., Anderson, H.M. 1985, Paleoflora of Southern Africa Prodromus of South African Megafloras Devonian to Lower Cretaceous. In: Balkema, A.A. (Ed.). Pretoria. 423p.

Arai, M., Rösler, O., 1984. Megásporos de São João do Triunfo, Formação Rio Bonito (Permiano). Bol. IG - USP 15, 53-64.

Barclay, R.S., Mcelwain, J.C., Duckett, J.G., Van Es, M., Mosaert, A.S., Pressel, S., Sageman, B.B., 2013. New methods reveal oldest known fossil epiphyllous moss: Bryiidites uthahenisi gen. et sp. nov. (Bryidae). Am. J. Bot. 100, 2450-2457. http://dx.doi.org/10.3732/ajb.1300209.

Bergamaschi, S., Oliveira, R.M.A.G., Campos, G.F., Souza, V.M.J.S., Pinto, G.P., Pessano, P.C., Ade, M.V.B., Pinheiro, A.E.P.P., Martins, M.V.A., 2016. Paleoenvironmental evolution of the Itararé group (Paraná Basin) in the regions of Salto and Itu, east of São Paulo state, Brazil. J. Sediment. Environ. 1, 145-158. http:// dx.doi.org/10.12957/jse.2016.21956.

Bernardes-de-Oliveira, M.E., Rohn, R., Ricardi-Branco, F., Zampirolli, A.P., Mune, S.E. Amaral, P.G.C. do, Longhim, M.E., Castro-Fernandes, M.C., Lages, L., 2005. Late Carboniferous to Early Permian glacial related paleofloras from northeastren Paraná Basin, Brazil. In: GONDWANA 12. Mendoza, 2005. Abstracts, Academia Nacional de Ciencias, 70.

Bharadwaj, D.C., 1957. The Palynological investigations of the Saar coals. Palaeontographica B101, 71-125.

Bell, N.E., Quandt, D., O'Brien, T.J., Newton, A.E., 2007. Taxonomy and phylogeny in the earliest diverging pleurocarps: square holes and bifurcating pegs. Bryologist 110, 533-560. http://dx.doi.org/10.1639/0007-2745(2007)110[533:TAPITE] 2.0.CO; 2 . 
Bocardi, L.B., Rostirolla, S.P., Vesely, F.F., França, A.B., 2009. Diagênese, contexto deposicional e história de soterramento da Formação Rio Bonito, Bacia do Paraná. Rev. Bras. Geociências 39, 465-478.

Bomfleur, B., Klymiuk, A.A., Taylor, E.L., Taylor, T.N., Gulbranson, E.L., Isbell, J.L., 2014. Diverse bryophyte mesofossils from the Triassic of Antarctica. Lethaia 47, 120-132. http://dx.doi.org/10.1111/let.12044.

Bonny, S., Jones, B., 2008. Experimental precipitation of Barite $\left(\mathrm{BaSO}_{4}\right)$ among streamers of sulfur-oxidizing bacteria. J. Sediment. Res. 78, 357-365. http:// dx.doi.org/10.2110/jsr.2008.038.

Bortoluzzi, C.A., Veiga, P., 1981. Considerações sobre a geologia da área dos afloramentos fossilíferos de São Sepé, RS. Pesquisas 14, 23-26.

Boyce, K., 2008. How green Cooksonia? the importance of size in understanding the early evolution of physiology in the vascular plant lineage. Paleobiology, 34: 179-194. doi: 10.1666/0094-8373(2008)034[0179:HGWCTI]2.0.CO;2

Castro, J.C., 2004. Glaciações Paleozóicas no Brasil. In: Mantesso-Neto, V., Bartorelli, A., Carneiro, C., Dal, R., Brito-Neves, B.B. (Eds.), Geologia do Continente Sul americano: Evolução da Obra de Fernando Flávio Marques de Almeida. Editora Beca, S. Paulo, SP, pp. 151-162.

Capretz, R.L., Rohn, R., 2013. Lower Permian stems as fluvial paleocurrent indicators of the Parnaíba Basin, northern Brazil. J. S. Am. Earth Sci. 45, 69-82. http:// dx.doi.org/10.1016/j.jsames.2012.12.007.

Cauduro, A.D., Zingano, A.G., 1965. Megáspores en argilete silicifié de São Sepé, Rio Grande do Sul. An. Acad. Bras. Ciências 37, 273-282.

Catuneanu, O., Wopfner, H., Eriksson, P.G., Cairncross, B., Rubidge, B.S., Smith, R.M.H., Hancox, P.J., 2005. The Karoo basins of south-central Africa. J. Afr. Earth Sci. 43, 211-253. http://dx.doi.org/10.1016/j.jafrearsci.2005.07.007.

Cristiano-de-Souza, I.C., Ricardi-Branco, F., León, V.Y., 2012. Permian bryophytes of western Gondwanaland from the Paraná Basin in Brazil. Palaeontology 55, 229-241. http://dx.doi.org/10.1111/j.1475-4983.2011.01111.x.

Désamoré, A., Laenem, B., Stech, M., Papp, B., Hedenäs, L., Mateo, R.G., Van Der Poortem, A., 2012. How do temperate bryophytes face the challenge of a changing environment? Lessons from the past and predictions for the future. Glob. Change Biol. 18, 2915-2924. http://dx.doi.org/10.1111/j.13652486.2012.02752.x.

Dijkstra, S.J., 1956. Some Brazilian megaspores, Lower Permian in age, and their comparision with Lower Gondwana spores from Índia. Meded. Geol. Strichting Nieuwe Ser. 9, 5-10.

Dybová-Jachowicz, S., Jachowichz, A., Karczwska, J., Lachkar, G., Loboziak, S., Piérart, P., Turnau, E., Zoldani, E., 1979. Note préliminaire sur la revision des megaspores à guls du Carbonifère. Les principes de la classification. Acta Palaeontol. Pol. 24, 411-422.

Dybová-Jachowicz, S., Jachowicz, A., Karczewska, J., Lachkar, G., Loboziak, S., Piérart, P., Turnau, E., Zoldani, E., 1987. Revision of Carboniferous megaspores with gula (Parth three). Pr. Inst. Geol. Varsóvia, 49p.

Faria, R.S., Ricardi-Branco, F., 2010. Lepidophylloides corumbataensis sp. nov. From Guadalupian in the Paraná Basin, southern Brazil. Rev. Palaeobot. Palynol. 160, 135-142. http://dx.doi.org/10.1016/j.revpalbo.2010.02.001.

Faria, R.S., Ricardi-Branco, F., Giannini, P.C.F., Sawakuchi, A.O., Del Ben, L.E.V., 2009. Lycopodiosis derbyi Renault from the Corumbataí formation in the State of São Paulo (Guadalupian of Paraná Basin, southern of Brazil): new data from compressed silicified stems. Rev. Palaeobot. Palynol. 158, 180-192. http://dx.doi.org/ 10.1016/j.revpalbo.2009.08.005.

Faria, R., Ricardi-Branco, F., Chistiano-de-Souza, I.C., 2013. Permian Leonardosia organic oospores from southern Brazil. Palaeontology 56, 797-805. http:// dx.doi.org/10.1111/pala.12016.

Ferreira-Oliveira, L.G., Rohn, R., 2010. Leaiid conchostracans from the uppermost Permian strata of the Paraná Basin, Brazil: Chronostratigraphic and paleobiogeographic implications. J. S. Am. Earth Sci. 29, 371-380. http://dx.doi.org/ 10.1016/j.jsames.2009.03.006.

Fielding, C.R., Frank, T.D., Isbell, J.L., 2008. The late Paleozoic ice age - a review of current understanding and synthesis of global climate patterns. Geol. Soc. Am. Special Pap. 441, 343-354. http://dx.doi.org/10.1130/2008.2441(24).

Frey, W. (Ed.), 2009. Syllabus of Plant Families. Bryophytes and Seedless Vascular Plant, 13 ed. Borntraeger, Berlin. 419p.

Garbary, D.J., Miller, A.G., Scrosati, R., Kwang-Young, K., Schofield, W.B., 2008. Distribution and salinity tolerance of intertidal mosses from Nova Scotian salt marshes. Bryologist, 111: 282-291. doi: 10.1639/0007(2008)111[282:DASTOI] 2.0.CO;2

Garcia, B.G., 1995. Palinologia de la Formación El Imperial, Paleozoico Superior, 32. Parte I: Esporas. Ameghiniana, Cuenca San Rafael, Argentina, pp. 315-339.

Gastaldo, R.A., 1988. A conspectus of phytotaphonomy. In: DiMichele, W.A., Wing, S.L. (Eds.), Methods and Applications of Plant Paleoecology. Knoxville, the Paleontological Society. University of Tennessee, pp. 14-28. Special Publication No. 3.

Gerrienne, P., Dilcher, D.L., Bergamaschi, S., Milagres, I., Pereira, E., Rodrigues, M.A.C., 2006. An exceptional specimen of the early land plant Cooksonia paranensis, and a hypothesis on the life cycle of the earliest eutracheophytes. Rev. Palaeobot. Palynol. 142, 123-130.

Glasspool, I.J., 2003. A review of Permian Gondwana megaspores, with particular emphasis on material collected from coals of the Witbank Basin of South Africa and the Sydney Basin of Australia. Rev. Palaeobot. Palynol. 124, 227-296. http:// dx.doi.org/10.1016/S0034-6667(02)00252-X.

Goffinet, B., Buck, W.R., Shaw, A.J., 2009. Morphology, Anatomy, and Classification of the Bryophyta. In: Goffinet, B., Shaw, A.J. (Eds.), Bryophyte Biology, second ed. Cambridge University Press, Cambridge, pp. 55-138.
Holz, M., França, A.B., Souza, P.A., Iannuzzi, R., Rohn, R., 2010. A stratigraphic chart of the Late Carboniferous/Permian succession of the eastern border of the Paraná Basin, Brazil, South America. J. S. Am. Earth Sci. 29, 381-399. http://dx.doi.org/ 10.1016/j.jsames.2009.04.004.

Hueber, F.M., 1961. Hepaticites devonicus, a new fossil liverwort from the Devonian of New York. Ann. Mo. Botanical Gard. 48, 125-132.

Hübers, M., Kerp, H., 2012. Oldest known mosses discovered in Mississippian (late Visean) strata of Germany. Geology 40, 755-758. http://dx.doi.org/10.1130/ G33122.1.

Johnson, M.G., Malley, C., Goffinet, B., Shaw, A.J., Wickett, N.J., 2016. A phylotanscriptomic analysis of gene family expansion and evolution in the largest order of pleurocarpous mosses (Hypnales, Bryophyta). Mol. Phylogenetics Evol. 98, 29-40. http://dx.doi.org/10.1016/j.ympev.2016.01.008.

Lewis, A.R., Marchant, D.R., Ashworth, A.C., Hedenas, L., Hemming, S.R., Johnson, J.V., Wolf, A., 2008. Mid-Miocene cooling and extinction of Tundra in continental Antarctica. PNAS 105, 10679-10680. http://dx.doi.org/10.1073/ pnas.0802501105.

Longhim, M.E., Souza, P.A., Rohn, R., 2002. Palinologia do Grupo Itararé na região de Salto (Carbonífero Superior), Estado de São Paulo, Brasil. Parte I - Palinologia Sistemática. Rev. Univ. Guarulhos-Geociências 8, 43-60.

Marques-Toigo, M., Corrêa, Z.C.S., Herter, G.G., 1975. Geology and palynology of Candiota coal mine, RS, Brazil. In: Actas Congreso argentino de Paleontologia y Bioestratigrafia, 1, pp. 401-427. Tucumán, Argentina.

Mezzalira, S., 1980. Bioestratigrafia do Grupo Passa Dois no Estado de São Paulo. Rev. IG 1, 15-34.

Milani, E.J., DeWitt, M.J., 2008. Correlations between the classic Paraná and CapeKaroo sequences of South America and southern Africa and their basin infills flanking the Gondwanides: du Toit revisited. Geological Society, London, pp. 319-342. Special Publications 294.

Milani, E.J., Faccini, U.F., Scherer, C.M.S., Araújo, L.M., Cupertino, J.A., 1998. Sequences and stratigraphic hierarchy of the Paraná Basin (Ordovician to Cretaceous), southern Brazil. Boletim IG-USP. São Paulo 29, 125-173.

Milani, E.J., Melo, J.H.G., Souza, P.A., Fernandes, L.A., França, A.B., 2007. Bacia do Paraná. Bol. Geociências Petrobrás 15, 265-287. http://dx.doi.org/10.1144/ SP294.17.

Mishler, B.D., Kelch, D.G., 2009. Phylogenimics and early land plant evolution. In: Goffinet, B., Shaw, A.J. (Eds.), Bryophyte Biology, second ed. Cambridge University Press, Cambridge, pp. 173-197.

Mune, S.E., Bernardes-de-Oliveira, M.E.C., 2007. Paleoflorística e Bioestratigrafia da Tafoflora de Monte Mor (SP), Subgrupo Itararé, NE da Bacia do Paraná. In: Carvalho, I.S., Cassab, R.C.T., Schanke, C., Carvalho, M.A., Fernandes, A.C.S., Rodrigues, M.A.C., Carvalho, M.S.S., Arai, M., Oliveira, M.E.Q. (Eds.), Paleontologia: Cenários de Vida. Ed. Interciência, pp. 71-81. Rio de Janeiro, Rj.

Neves, J.P., Rohn, R., Simões, M.G., 2011. Tafonomia de tempestitos conchíferos amalgamados da formação Teresina em Rio Preto (Estado do Paraná, Permiano Médio, Bacia do Paraná) e suas Implicações Paleoambientais. Geologia USP. Série Científica 11, 131-147. http://dx.doi.org/10.5327/Z1519874X2011000300008.

Ochyra, R., Lewis-Smith, R.I., Bednarek-Ochyra, H., 2008. The Illustrated Moss Flora of Antarctica. Cambridge University Press, Cambridge, UK, 704p.

Pant, D.D., 1962. The classification and the nomenclature of fossil megaspores. Bull. Botanical Surv. India 4, 155-160.

Pant, D.D., Srivastava, G.K., 1962. Structural studies of Lower Gondwana megaspores Part II. Specimens from Brazil and mhukuru coalfielf, tangayika. Palaeontographica 111B, 96-111.

Parrish, J.M., Parrish, J.T., Ziegler, A.M., 1986. Permian-Triassic paleogeography and paleoclimatology and implications for Therapsid distribution. In: Hotton, N. Maclean, P.D., Roth, J.J., Roth, E.C. (Eds.), The Biology and Ecology of Mammallike Reptiles. Smithsonian Press, Washington, D. C., pp. 109-132

Piérart, P., 1975. Systématique, distribution stratigraphique et géographique des mégaspores du Carbonifére et du Permien. Compte Rendu 7 Congrés International de Stratigraphie et de Geológie du Carbon. Kiefeld 4, 93-102.

Piérart, P., 1981. Stratigraphical and géographical distribution of Gondwana megaspores. In: Selected Papers and Abstracts 5 International Gondwana Symposium, pp. 19-21. Wellington.

Piérart, P., 1984. Les mégaspores du Carboniferè et du Gondwana inférieuer de l'Afrique et de l'Amerique du Sud. Bulletim Sceances la Acad. das Sceances O.-m. 28, 155-163.

Potonié, R., Kremp, G., 1954. Die gattungen der Paläozoischen Sporae dispersae und ihre Stratigraphie. Geol. Jahrb. 69, 111-194.

Ricardi-Branco, F., Arai, M., Rösler, O., 2002. Megaspores from coals of the triunfo member, rio Bonito Formation (Lower Permian), northeastern Paraná state, Brazil. An. Acad. Bras. Ciências 74, 491-503.

Ricardi-Branco, F., Costa, J.S., Cristiano-de-Souza, I.C., Rohn, R., Longhim, M., Faria, R.S., 2013. Bryophytes associated with Pennsylvanian periglacial environments in southern Gondwana (São Paulo state, Itararé group, Paraná Basin, Brazil). Bull. N. M. Mus. Nat. Hist. Sci. 60, 343-347.

Rigby, J.F., 1968. Nova localidade de plantas fósseis próxima a Laras, Estado de São Paulo. In: Sumário das comunicações e conferências 22th Congresso Brasileiro de Geologia, Belo Horizonte, pp. 65-66.

Rocha-Campos, A.C., Santos, P.R., dos, Canuto, J.R., 2008. Late Paleozoic glacial deposits of Brazil: Paraná Basin. Geol. Soc. Am. Bull. 441, 97-114. http://dx.doi.org/ 10.1130/2010.2468(00).

Rohn, R., 2001. A estratigrafia da Formação Teresina (Permiano, Bacia do Paraná) de acordo com furos de sondagem entre Anhembi (SP) e Ortigueira (PR). In: 
Melo, J.H., Terra, G.J.S. (Eds.), Correlação de sequências Paleozóicas SulAmericanas. Ciência-Técnica-Petróleo. Seção: Exploração de Petróleo, 20, pp. 209-218.

Rohn, R., 2007. The Passa Dois Group (Paraná Basin, Permian): Investigations in Progress. In: Extended Abstracts Workshop - Problems in the Western Gondwana Geology, South America - Africa correlations: Du Toit revisited, 1. UFRG, Porto Alegre, pp. 151-157.

Rohn, R., Fairchild, T.R., 2015. Microbialitos do Grupo Passa Dois, Permiano InferiorMédio, Bacia do Paraná, estados de São Paulo e Paraná. In: Fairchild, T.R. Rohn, R., Dias-Brito, D. (Eds.), Microbialitos do Brasil do Pré-Cambriano ao Recente: um atlas. Rio Claro, UNESP - IGCE - UNESPetro, Obra 2, pp. 270-317.

Rohn, R., Longhim, M.E., Bernardes-de-Oliveira, M.E., Navarro, G.R.B., 2000. Nova ocorrência fitofossilífera neocarbonífera-eopermiana do Subgrupo Itararé, à margem esquerda do rio Capivari, Município de Tietê, SP, Brasil. Revista Universidade Guarulhos. Geociências 5, 57-61.

Rösler, O., 1978. The Brazilian eogondwanic floral succession. Bol. IG-USP 9, 85-91.

Schimper, W.P., 1879. Palaeophytologie. In: Von Zittel, K.A. (Ed.), Handbuch der Palaeontologie. Publisher, München, pp. 73-209, 958.

Shelton, W.K., Stockey, R.A., Rothwell, G.W., Tomescu, A.M.F., 2015. Exploring the fossil history of plaeuricarpous mosses: tricostaceae fam. nov. from Cretaceous of Vancouver Island, Canada. Am. J. Bot. 102, 1883-1900. http://dx.doi.org/ 10.3732/ajb.1500360.

Souza, P.A., 2006. Late Carboniferous palynostratigraphy of the Itararé subgroup, northeastern Paraná, basin, Brazil. Rev. Palaeobot. Palynol. 138, 9-29. http:/ dx.doi.org/10.1016/j.revpalbo.2005.09.004

Souza, P.A., Amaral, P.G.C., Bernardes de Oliveira, M.E.C., 2006. A Late carboniferous palynoflora from the Itararé subgroup (Paraná Basin), Campinas, São Paulo state, Brazil. Rev. Micropaléontologie 49, 105-115. http://dx.doi.org/10.1016/ j.revmic.2006.03.002.

Souza, P.A., Felix, C.M., Perez-Aguilar, A., Petri, S., 2010. Pennsylvanian palynofloras from the Itu rhythmites (Itararé subgroup, Paraná Basin) in São Paulo state, Brazil. Rev. Micropaléontologie 53, 69-83. http://dx.doi.org/10.1016/ j.revmic.2008.10.003.

Souza Filho, E.E. de, 1986. Mapeamento faciológico do Subgrupo Itararé na quadrícula de Campinas (SP). Master Thesis. Instituto de Geociências, Universidade de São Paulo.

Taylor, T.N., Taylor, E.L., Krinks, M., 2009. Paleobotany: the Biology and Evolution of Fossil Plants. Academic Press - Elsevier, New York, 1230p.

Trindade, N.M., 1959. O gênero Lagenosporites no Gondwana brasileiro. Notas Prelim. Estud. DNPM 112, 1-13.

Trindade, N.M., 1962. Megásporos gondwânicos da Mina do Leão, Rio Grande do Sul. Notas Prelim. Estud. DNPM 118, 1-22.

Trindade, N.M., 1964. Megásporos gondwânicos de Charqueadas. Rio Gd. do Sul ii. Bol. do DNPM 26, 1-27.

Trindade, N.M., 1966. Sinopse da sistemática dos megásporos do Gondwana brasileiro. An. Acad. Bras. Ciências 43, 351-361.

Trindade, N.M., 1970. Megásporos carboníferos de Monte Mor, Estado de São Paulo. An. Acad. Bras. Ciências 42, 459-470.

Vesely, F.F., Assine, M.L., 2006. Deglaciation sequences in the Permo-Carboniferous Itararé group, Paraná Basin, southern Brazil. J. S. Am. Earth Sci. 22, 156-168. http://dx.doi.org/10.1016/j.jsames.2006.09.006. 